\title{
MANAGEMEN REKTUTMEN VOLUNTERS ASIAN PARA GAMES CABANG OLAHRAGA BULUTANGKIS TAHUN 2018
}

\author{
Helen Purnama Sari ${ }^{1}$ \\ Novri Asri \\ M. Al Ghani ${ }^{3}$ \\ helenpurnamasari20@gmail.com
}

\begin{abstract}
Abstrak
Penelitian dilakukan di Jakarta tepatnya pada PP PBSI Selama 1 bulan, dengan terlebih dahulu peneliti melakukan observasi dan kemudian melakukan penelitian dan pengambilan data pada tanggal 29 Januari 2019 sampai dengan tanggal 29 Februari 2019. pendekatan yang digunakan dalam penelitian ini adalah kualitatif dengan model countenance dari Stake dimana dalam model ini meliputi tiga hal yakni keadaan sebelum kegiatan berlangsung (antencendents), kegiatan yang terjadi (transactions) dan hasil yang diperoleh (outcomes). Dalam pengambilan subyek peneliti menggunakan teknik purposive sampling. Hasil penelitian Antecedents dalam hal ini yakni kelengkapan perangkat sudah terstruktur dimana sudah ada struktur kepengurusan yang jelas dan adanya program kegiatan yang sudah terencana dan terjadwal dengan baik dan dapat teraplikasikan sesuai dengan program kegiatan yang ada. transaction terkait proses seleksi sudah berjalan dengan baik dan sesuai prosedur. Outcomes (prestasi) berhasil mensukseskan Asian Para Games cabang olahraga bulutangkis.
\end{abstract}

Kata Kunci : Manajemen, Volunters, Bulutangkis

\begin{abstract}
The research was conducted in Jakarta precisely on PP PBSI for 1 month, with researchers first observing and then conducting research and data collection on January until February. The approach used in this study was qualitative with a model of countenance from Stake where in this model includes three things namely the condition before the activity takes place (antencendents), activities that occur (transactions) and the results obtained (outcomes). In taking subject researchers using purposive sampling technique. The results of the Antecedents research in this case are the completeness of the structured device where there is already a clear management structure and a well planned and scheduled activity program that can be applied in accordance with the existing program of activities. transactions related to the selection process have gone well and according to the procedure. Outcomes have succeeded in making the Asian Para Games a success in badminton.
\end{abstract}

Keywords :Managemen, Volunters, badminton

Dipublikasikan Oleh :

UPT Publikasi dan Pengelolaan Jurnal

Universitas Islam Kalimantan Muhammad Arsyad Al-Banjari Banjarmasin 


\title{
PENDAHULUAN
}

Asian Para Games yang di adakan di Indonesia merupakan suatu bukti bahwa Indonesia mampu menjadi tuan rumah yang baik dengan sumberdaya manusianya yang luar biasa kreatif, aktif dan dapat bekerja dengan baik sesuai bahkan lebih dari tupoksi yang seharusnya, terbukti dengan banyaknya pujian pada berbagai asfek Volunters yang ada yang ikut berpartisipasi dalam kegiatan tersebut. Pada penelitian ini peneliti ingin mengetahui sistem rekrutmen dan managemen dalam perekrutan volunters yang terdiri dari Sumber daya manusia yang bekerja sebagai pendukung dan petugas dalam kegiatan kejuaraan asian para games cabang olahraga bulutangkis terdiri atas Line Jugde, wasit, koordinator lapangan, match control, Liason Officer, koordinator atlet, pelatih dan official.

Berdasarkan hasil wawancara bersama Bapak Nelson 19 September 2018 selaku salah satu Ketua bidang pertandingan dan koordinator Linejugde (Volunters) cabang olahraga Bulutangkis pada Asian Games beliau mengatakan bahwa "volunters yang direkrut sangat membantu berjalannya kegiatan ini bahkan mereka sudah bekerja sesuai dengan ketentuan sebagai volunters yang tidak terkesan baru bergabung tetapi sudah seperti berpengalaman padahal hal ini baru mereka dapatkan saat ini”.

Dalam proses rekrutmen ternyata para volunters ini harus melewati banyak proses dan inilah yang ingin diambil oleh peneliti sebagai contoh perekrutmenan yang bisa diaplikasikan kedalam suatu kegiatan, mulai dari proses awal pemilihan, penyeleksian sampai dengan terpilihnya mereka sebagai volunters di Asian para games 2018.

\section{METODE}

Penelitian kualitatif merupakan prosedur penelitian yang menghasilkan data deskriptif berupa katakata yang terucapkan secara lisan dan tertulis serta perilaku orang. Penelitian kualitatif selalu berlatar alamiah dan sumber datanya berkonteks sewajarnya (natural setting). Pendekatan yang dilakukan dalam penelitian ini adalah pendekatan countenance dari Stake,yang meliputi keadaan sebelum berlangsung (antecedents), kegiatan yang terjadi dan saling mempengaruhi (transactions) serta hasil yang diperoleh (outcomes) dimana model Stake menitikberatkan evaluasi pada dua hal pokok yaitu description dan judgement.

Pendekatan penelitian ini menggunakan pendekatan kualitatif dengan model countenance dari Stake dimana dalam model ini meliputi tiga hal yakni keadaan sebelum kegiatan berlangsung (antencendents), kegiatan yang terjadi (transactions) dan hasil yang diperoleh (outcomes). Subyek penelitan ini adalah pengurus, volunters, atlet dan masyarakat. Dalam pengambilan subyek peneliti menggunakan teknik purposive sampling. Teknik purposive sampling adalah pengambilan sumber data dengan pertimbangan tertentu (Sugiyono,2010:54). Pengumpulan data merupakan salah satu tahapan sangat penting dalam penelitian. Di dalam metode penelitian kualitatif, lazimnya data dikumpulkan dengan beberapa teknik pengumpulan data kualitatif, yaitu; 1) wawancara, 2) observasi, 3) dokumentasi, dan 4) diskusi terfokus.(http://mudjiahardjo.com/artikel/336.html?task=view)

Bungin (2007: 115-117) mengemukakan beberapa bentuk observasi, yaitu: 1) observasi partisipasi, 2) observasi tidak terstruktur, dan 3) observasi kelompok, Agar wawancara efektif, maka terdapat berapa tahapan yang harus dilalui, yakni ; 1) mengenalkan diri, 2) menjelaskan maksud kedatangan, 3) menjelaskan materi wawancara, dan 4) mengajukan pertanyaan (Yunus, 2010: 358).

\section{HASIL DAN PEMBAHASAN}

Penelitian dilakukan di Jakarta tepatnya pada PP PBSI Selama 1 bulan, dengan terlebih dahulu peneliti melakukan observasi dan kemudian melakukan penelitian dan pengambilan data pada tanggal 29 Januari 2019 sampai dengan tanggal 29 Februari 2019 diantaranya melakukan observasi, wawancara dan dokumentasi pada managemen rekrutment Volunters Asian Para Games cabang olahraga Bulutangkis tahun 2018.

Penelitian ini mengungkap 3 komponen yang terdapat pada Managemen rekrutmen Volunters Asian Para Games cabang olahraga Bulutangkis tahun 2018 yang meliputi : meliputi 3 hal yakni antecendents, transaction dan outcomes. Dimana untuk antecendents terdari dari aspek Tujuan perekrutan volunters, program kegiatan dan kelengkapan perangkat Managemen rekrutmen Volunters Asian Para

\author{
Dipublikasikan Oleh : \\ UPT Publikasi dan Pengelolaan Jurnal \\ Universitas Islam Kalimantan Muhammad Arsyad Al-Banjari Banjarmasin
}


Games 2018 cabang olahraga Bulutangkis, untuk transaction nya terdiri dari seleksi volunters, sarana dan prasarana, pelaksanaan program kegiatan, konsumsi, kesejahteraan dan untuk aoutcomes nya yakni hasil yang didapatkan keberhasilan dan prestasi yang didapat.

Tabel 1 Hasil Penelitian Terhadap Aspek-Aspek dalam Tahapan management Antecedents (masukan),Transaction (proses) dan Outcomes (hasil) Managemen rekrutmen Volunters Asian Para Games 2018 cabang olahraga Bulutangkis tahun 2018

\begin{tabular}{|c|c|c|c|}
\hline No & $\begin{array}{l}\text { Tahapan } \\
\text { Evaluasi }\end{array}$ & Aspek yang diungkap & Keterangan \\
\hline \multirow[t]{3}{*}{1} & \multirow[t]{3}{*}{$\begin{array}{l}\text { Antecedents } \\
\text { (masukan) }\end{array}$} & $\begin{array}{l}\text { 1. Tujuan } \\
\text { volunters }\end{array}$ & $\begin{array}{l}\text { Mensukseskan penyelenggaraan Asian Para } \\
\text { Games Cabang olahraga Bulutangkis, } \\
\text { menciptakan para Volunters yang } \\
\text { berkompeten dan dapat di andalkan dalam } \\
\text { berbagai kegiatan yang akan datang, } \\
\text { menciptkan pertandingan yang adil dan } \\
\text { profesional, mempersiapkan para Volunters } \\
\text { yang dapat memberikan pelayanan yang baik } \\
\text { bagi seluruh peserta baik atlet, pelatih, } \\
\text { official dan tamu kenegaraan yang hadir } \\
\text { pada cabang olahraga bulutangkis }\end{array}$ \\
\hline & & 2. program kegiatan & $\begin{array}{l}\text { Adanya kegiatan yang telah disusun dan } \\
\text { harus diikuti oleh seluruh volunters cabang } \\
\text { olaharaga bulutangkis (terlampir) }\end{array}$ \\
\hline & & 3. kelengkapan perangkat & $\begin{array}{l}\text { Adanya struktur yang menaungi kegiatan ini, } \\
\text { adanya pemerintahan dibawah pimpinan } \\
\text { Pemerintahan RI, INAPGOC, PP PBSI } \\
\text { dengan struktur kepengurusan }\end{array}$ \\
\hline \multirow[t]{4}{*}{2} & \multirow[t]{4}{*}{$\begin{array}{l}\text { Transaction } \\
\text { (proses) }\end{array}$} & 1. seleksi volunters & $\begin{array}{l}\text { Para volunters sudah sesuai dengan kriteria } \\
\text { yang ditentukan oleh panitia cabang olahraga } \\
\text { bulutangkis dalam hal ini PP PBSI dan } \\
\text { sudah melewati berbagai proses evaluasi dan } \\
\text { karantina dalam menerima berbagai } \\
\text { pembelajaran terkait apa yang harus } \\
\text { dilakukan dan tugas apa yang harus } \\
\text { dikerjakan }\end{array}$ \\
\hline & & 2. konsumsi, & $\begin{array}{l}\text { Sudah ada Konsumsi yang diberikan berupa } \\
\text { makanan (makan pagi, makan siang dan } \\
\text { makan malam), snack dan air mineral rutin } \\
\text { setiap hari }\end{array}$ \\
\hline & & 3. Sarana dan prasarana & $\begin{array}{l}\text { Sarana dan prasarana diberikan oleh } \\
\text { kementerian perhubungan yang langsung } \\
\text { dikomunikasihkan dengan seluruh panitia } \\
\text { (volunters) cabang olahraga bulutangkis } \\
\text { sudah sesuai dengan standar,cukup untuk } \\
\text { atlet, pelatih, dan official, tempat duduk } \\
\text { nyaman, ber } A C \text { dan memang kendaraan } \\
\text { dalam keaadaan layak pakai serta terpelihara } \\
\text { dengan baik }\end{array}$ \\
\hline & & $\begin{array}{l}\text { 4. pelaksanaan program } \\
\text { kegiatan, }\end{array}$ & $\begin{array}{l}\text { Pelaksanaan kegiatan sudah terjadwal dan } \\
\text { terprogram sesuai dengan kegiatan yang } \\
\text { akan dijalani pada cabang olahraga } \\
\text { bulutangkis, berdasarkan waktu dan tempat } \\
\text { yang telah ditentukan saat technical meeting }\end{array}$ \\
\hline
\end{tabular}

Dipublikasikan Oleh :

UPT Publikasi dan Pengelolaan Jurnal

Universitas Islam Kalimantan Muhammad Arsyad Al-Banjari Banjarmasin 


\begin{tabular}{|c|l|l|l|}
\hline \multirow{2}{*}{} & & & dan briefing dilaksanakan \\
\cline { 3 - 5 } & 5. kesejahteraan & $\begin{array}{l}\text { Para volunters mendapatkan honor yang } \\
\text { didapat langsung dari kementerian keuangan } \\
\text { yang di wakilkan pada INAPGOC dan } \\
\text { diserahkan langsung kepada volunters yang } \\
\text { berrsangkutan melalui via Atm pribadi } \\
\text { masing-masing }\end{array}$ \\
\hline 3 & $\begin{array}{c}\text { Outcomes } \\
\text { (hasil) }\end{array}$ & $\begin{array}{l}\text { hasil yang didapatkan } \\
\text { keberhasilan serta kepuasaan } \\
\text { para atlet, pelatih dan official }\end{array}$ & $\begin{array}{l}\text { Para volunters berhasil memberikan yang } \\
\text { terbaik, adanya appresiasi dari ketua } \\
\text { INAPGOC Indonesia adanya berbagai } \\
\text { pujian dari berbagai kalangan mancan } \\
\text { negara, dan dengan di percayainya Indonesia } \\
\text { dalam menyambut Olimpiade mendatang } \\
\text { sebagai tuan rumah }\end{array}$ \\
\hline
\end{tabular}

(Sumber: Hasil observasi, wawancara dan dokumentasi )

Berdasarkan data diatas maka dapat disimpulkan bahwa Managemen rekrutmen Volunters Asian Para Games 2018 cabang olahraga Bulutangkis yang telah berjalan sudah sangat baik, sehingga dengan keberhasilan yang dapat diapat maka proses seleksi yang telah diselenggarakan dapat di aplikasikan untuk kedepannya, dapat dijadikan contoh sebagai acuan dalam proses menyeleksi dan merekrut calon-calon pekerja, mulai dengan diadakannya proses perekrutan, prosesnya dan sistem evaluasinya secara menyeluruh baik itu dari aspek Program kegiatan, mulai dari apa saja yang dilakukan, apa yang yang dikerjakan bagaimana prosesnya dan bagaimana sistem pekerjaan yang mereka lakukan.

Program kegaiatan yang sudah tersusun dan terencana memudahkan para volunters untuk memahami apa saja yang akan dikerjakannya, terlebih adanya tim yang melakukan evaluasi dalam setiap kegiatan yang dilakukan oleh para volunters menjadi sebagai pecutan untuk mereka bersemangat dalam melaksanakan tugas yang diberikan, adanya tujuan dari setiap proses yang dilakukan, misalnya mengapa diadakan seleksi kenapa tidak asal ambil dan di training langsung, tapi sesuai dengan tujuan awal bahwa PP PBSI ingin benar-benar memberikan yang terbaik sesuai dengan arahan INAPGOC sebagai panitia besar dalam kegiatan asian para games cabang olahraga bulutangkis tahun 2018 .

Asian Para games cabang olahraga bulutangkis tahun 2018 harus berhasil tanpa keluhan yang bererati dan harus terlaksana dengan sebaik mungkin, begitupun dengan struktur yang ada, pada cabang olahraga bulutangkis memang telah ada struktur yang bertugas, muali dari ketua NPC dalam hal ini diwakilkan bapak jaohari latief, ketua bidang pertandingan dalam hal ini oleh bapak Nelson, sehingga para volunters jelas dibawah wewenang struktur ada yang menaungi, terkait mengenai konsumsi para volunters dijamin mengenai konsumsi dan akomodasinya, mulai disediakannya makanan di pagi hari oleh pihak hotel yang dimana para volunters tingggal memilih makanan apa yang akan disantapnya, tersedia dengan berbagai varian yang tentunya higenis dan bergizi, untuk makan siang memang langsung disediakan oleh tim catering yang sudah terjadwal waktunya sehingga para volunters tidak akan merasa kelaparan dan harus keluar istora untuk mencari makan, untuk makan malam sudah disediakan oleh pihak hotel setelah selesai kejuaraan setiap harinya sampai kejuaraan berakhir.

Kesejahteraan para volunters sudah ada sejak mereka terpilih sebagai volunters resmi Asian Para games cabang olahraga bulutangkis mereka sudah di berikan hak kesejahteraan yang akan dibayarkan saat kegiatan berakhir dengan jumlah yang cukup besar dan diserahkan langsung pada masing-masing yang bersangkutan melalui via ATM kerekening masing-masing dan tidak ada keterlambatan sehingga mereka tidak hanya melaksanankan kegiatan dengan suka rela tetapi ada pendapatan yang akhirnya mereka peroleh sebagai bentuk penghargaan negara terhadap setiap kegiatan, energi dan usaha yang telah para volunters sumbangakan untuk kesuksesan asian para games cabang olahraga bulutangkis.

\section{PENUTUP}

\section{Kesimpulan}

Dipublikasikan Oleh :

UPT Publikasi dan Pengelolaan Jurnal

Universitas Islam Kalimantan Muhammad Arsyad Al-Banjari Banjarmasin 
Pembahasan mengenai Managemen Rekrutmen Volunters Asian Para Games Cabang Olahraga Bulutangkis tahun 2018 dapat disimpulkan sebagai berikut :

1) Antecedents dalam hal ini yakni kelengkapan perangkat sudah terstruktur dimana sudah ada struktur kepengurusan yang jelas dan adanya program kegiatan yang sudah terencana dan terjadwal dengan baik dan dapat teraplikasikan sesuai dengan program kegiatan yang ada.

2) Transaction terkait proses seleksi, sudah ada proses seleksi yang dilakukan, mulai dari volunters harus bisa berbahasa inggris, memahami tentang bulutangkis, disiplin, mampu membaur dan dilakukan evaluasi secara berkesinambungan, sarana dan prasarana yang didapat sudah sangat baik, mulai dari transfortasi yang tidak terhambat dalam menjalankan kegiatan, shuttlebus yang sudah tersedia sangat membantu para volunters untuk melayani para atlet, official dan berbagai tamu negara lainnya, penginapan yang sudah berbintang lima membuat para volunters sangat nyaman dalam menjalankan tugas, konsumsi yang sudah terjadwal dan sangat layak dimana para volunters dijamin makannya sebaik 3 kali sehari yakni pada sarapan pagi, makan siang dan makan malam. Untuk kesejahteraan para volunters mendapatkan honor sebesar Rp. 11.000 .000 selama 2 minggu yang dibayarkan langsung ke rekening pribadi masing-masing.

3) Outcomes (prestasi) berhasilnya para volunters dalam mensukseskan asian para games cabang olahraga bulutangkis, menuai banyak pujian tidak hanya didalam negara tetapi diluar negara Republik Indonesia bahkan Indonesia dinyatakan berhak menjadi tuan rumah olimpiade atas apa yang diberikan oleh para volunters selama menyambut pesta olahraga Asian para Games khususnya cabang olahraga bulutangkis. .

Hal ini terlihat dari banyaknya berbagai informasi mengenai keberhasilan pergelaran kejuaraan olahraga Asian Para games yang dilaksanakan di Indonesia tepatnya di Ibu kota DKI Jakarta, tercapainya target INAPGOC dalam hal ini yang langsung di beri mandat kepada PP PBSI dalam mensukseskan kegiatan Asian Para games cabang olahraga bulutangkis tahun 2018.

\section{REFERENSI}

Bungin, M. Burhan. 2007. Penelitian Kualitatif: Komunikasi, Ekonomi, Kebijakan Publik, dan Ilmu Sosial Lainnya. Jakarta: Kencana Prenada Media Group.

(http://mudjiahardjo.com/artikel/336.html?task=view)

Miltiadis Proios,2013. Management of Ethical Problems in Sport Within the Justice Framework. http://www.ijsmart.eu/onlinepic/vol 11_c\%20Miltiadis\%20 Proios.Pdf.

Sugiyono. 2010. Metode Penelitian Pendidikan Pendekatan Kuatitatif, Kualitatif, Dan R\&D. Bandung: Alfabeta.

Undang-Undang Republik Indonesia No 3 Tahun 2005 Tentang Sistem Keolahragaan Nasional. 2005. Jakarta: Lembaran Negara Republik Indonesia.

Wawancara : Nelson, Kepala Bidang turnamen dan pertandingan PP PBSI.

Wawancara :Jaohari Latief, Kepala bidang pembinaan turnamen dan pertandingan NPC.

Yunus, Hadi Sabari. 2010. Metodologi Penelitian Wilayah Kontemporer. Yogyakarta: Pustaka Pelajar.

Dipublikasikan Oleh :

UPT Publikasi dan Pengelolaan Jurnal

Universitas Islam Kalimantan Muhammad Arsyad Al-Banjari Banjarmasin 